\title{
DEMOCRATIC CONTROL OF ATOMIC POWER DEVELOPMENT
}

\author{
MORgan ThOMAs
}

Atomic power is a new source of energy which complements the older power sources found in coal, oil, and natural gas. Although it involves a technology developed and held in restricted form by the Government, it is filled with industrial potential for the national welfare and for the nation's business. Important for these reasons, it is placed on the battleground where American public policy is formulated.

Both domestic and foreign policy are concerned with progress in making nuclear power a practical, economic reality. Domestically, it has a great potential effect on the economic balance of forces. Internationally, it has the characteristic of a much desired body of new knowledge and new techniques which major powers can take to underdeveloped nations in return for their friendship and support. Hence, atomic power cuts into the conflict of contending forces at odds over governmental policies. It catches up the political partisans and gains their artful attention and publicizing. In short, an open struggle of the American system of democratic control is emerg. ing, with all the trappings of pressure groups, partisan forces in Congress and the Executive Branch, and frequent treatment by opinion-leaders, such as commentators, prominent businessmen, editorial writers, and national news magazines. A lively subject for "issues" is moving into prominence on the American stage of public policymaking.

The highly charged political characteristics of atomic power contrast rather sharply with the general low level of political involvement to which the field of atomic energy has previously been subjected. Atomic energy policy has been defense policy, largely formulated in secret within government councils of officials and securitycleared advisors. From time to time, some questions have spilled out into the public domain. One was the security policy of the Lilienthal Commission, as seen in the so-called Hickenlooper inquiry-the investigation of the AEC in 1949 by the Joint Committee on Atomic Energy. Another was the decision to go ahead with an H-bomb "crash" program. However, it was made public only as limited, after-the-fact information. Some other important decisions, too, were kept completely hidden from the public when made-e.g., the addition of production reactors and heavy water manufacturing plants at Savannah River and the establishment of a new experimental weapons laboratory at Livermore, California. And the public learned of the decision to enter upon a tremendous expansion of gaseous

* A.B. I938, Lafayette College; A.M. 1940, Ph.D. 1946, Harvard University. Associatc Professor of Political Science, University of Michigan. From 1952 to 1955 , in charge of research project No. 48, Michigan Memorial-Phoenix Project, University of Michigan. Author of the forthcoming Alomic Energy and Congress. 
diffusion plants only through the involvement of the congressional appropriations committees in the summer of 1952 . Therefore, on the whole, no active outside groups took stands, no commentators presented conflicting views, and democratic control over the Atomic Energy Commission came largely from commission advisers, from members of the Joint Committee on Atomic Energy, and, on some issues, from the President and his immediate staff.

Over all, the defense nature of the program facilitated fairly unanimous resolution of small differences. Occasionally, disputes within the "inner control groups," behind the cloak of secrecy, did manifest themselves, but they were not of long duration. For example, President Eisenhower eliminated the prototype of an aircraft carrier reactor from the budget estimates in the spring of 1953 , but, on the instigation of the Joint Committee on Atomic Energy, and with the help of the appropriations committees, the item was converted into a large-scale prototype of a centralstation power plant which the AEC was encouraged to start. Thus, policy was worked out by a governmental control group. It served, to be sure, as an instrument of public control, but it was not held accountable by the support or opposition of outside groups or forces. The political representatives who made up the control group recognized their responsibility to test the atomic energy program by their own interpretation of what would best serve the nation, but there was no real democratic check on this interpretation. ${ }^{1}$

Today, however, atomic power is ushering in a new set of conditions for public control. As the immediate concern of pressure groups, it enters an area where two entrenched and bitter opponents, public-power advocates and private-power advocates, fight with all the available political weapons. Furthermore, as the day dawns when private participation in atomic power begins and chances for private profit appear on the horizon, forces of self-interest are unleashed. Thus, the different businesses affected, such as the electric power, chemical engineering, and electric equipment manufacturing industries, see their rival and complementary positions in alternative schemes for development of atomic power. The forces of private initiative bring their inevitable concomitants, those of monopoly and favoritism. And the individuals and groups in our society who worry about these forces enter the fray. The Government's vast investment provides a source from which insiders and especially advantaged firms can benefit at the cost of others. The charge of "give-away" is heard. The manifestations of democratic political control have come on the scene.

The emergence of many aspects of democratic public control does not mean, however, that the technical information necessary for work in the field of atomic power has been wholly declassified. The reason for this is that the Government's program of research and development in reactors is a combined military-civilian program. The same reactor technology applies to the military field as to the civilian. Military

\footnotetext{
${ }^{1}$ For a general and more extended discussion of the foregoing, see Morgan Thomas, Atomic Energy AND Congress (to be published by the University of Michigan Press in March 1956).
} 
reactors are also producers of atomic power; they are being designed to drive submarines or surface vessels, to heat gases for jet propulsion in aircraft, and to provide electric current for portable-package power plants for military installations. In addition, reactor technology is vital for production reactors in which plutonium for atomic weapons is produced. Hence, because of the interchangeability of information, considerable secrecy of technical features remains.

This fact has several consequences of significance for public control. It means that outside analysts and public opinion leaders must guess and speculate about certain features of the various power reactors. The resulting estimates, often conflicting, cannot be affirmed or denied by government technicians for fear of revealing secret information. A general impression of confusion and uncertainty prevails. And although specially designated industrial groups are allowed access to secret technical information, this participation, no matter how widespread, is no substitute for general knowledge. Open discussion continues to be restricted, chances for special advantage obtain, and peaceful atomic power cannot be fitted completely into the normal system of democratic public control.

Yet, there is more and more publicity about the actual policy decisions which channel government and private resources into different parts of the reactor program. To be sure, the Commission classified its schedule of prices to be paid to industrial producers of special nuclear materials (plutonium and U-233). However, it revealed that the prices were based mainly on the "fuel value" of plutonium rather than the "military value" of the material for weapons use. ${ }^{2}$ Thus, without stating these prices in the exact dollar amounts, the Commission did release enough information so that the fundamental policy decision is clear: the Government will not give subsidies to atomic power producers in the form of high guaranteed prices for produced plutonium.

In short, in spite of the remaining secrecy, general public knowledge and discussion of atomic power are increasing and will doubtless continue to grow as declassification proceeds. As more and more groups become familiar and involved, the forces of democratic control will enlarge their impact on the field of atomic power policy. It is with this trend that this paper is concerned-with both the issues that are evolving and the clashes these issues are occasioning among the various economic, social, and governmental groups which are affected by the emergence of nuclear power.

\section{Speed of the Government's Program}

The AEC has drawn up a Five-Year Power Reactor Development Program to guide its own efforts in civilian reactor research and development work. This is based on the policy that it is the Government's responsibility to develop power reactor technology "to the point where one or more power reactor systems are technically and economically feasible, and beyond that, to develop technology for

${ }^{2}$ See Hearings before the Joint Committee on Atomic Energy on Development, Growth, and State of the Atomic Energy Industry, 84th Cong., Ist Sess., pt. I, at 73-76 (1955). 
even more advanced types of power reactors." In this program, the Commission uses mostly government money for planning and building experimental reactors of moderate size, although it was decided in 1953 to build one large-scale facility, the pressurized water reactor and power plant now under construction at Shippingport, Pennsylvania.

This program requires only brief comment, for it has never been the subject of controversy. It is true that the National Coal Association publicly deplored the Government's decision to ${ }^{4}$

... use huge amounts of taxpayers' money to construct, or to subsidize the construction of, numerous permanent installations [e.g., the Shippingport reactor] which admittedly will not be capable of producing electricity at a price which is competitive with coal.

However, even the Coal Association did not take issue with the AEC's five-year program as a whole, but simply recommended that the Government concentrate on laboratory research and temporary, pilot-scale experimental plants to obtain knowledge which would render nuclear power useful at a later time.

The lack of opposition to the AEC's civilian reactor program is traceable to the fact that several groups see value in it for different reasons. Those who favor the United States' progress in peacetime atomic power for international reasons are encouraged. There are practical arguments that the greatest industrial nation on earth will remain so only if we lead the world in every race for new technological discoveries. Quick achievement of practical atomic power is deemed to be in the public interest, and there is general agreement that the United States Government should continue to take the lead in its attainment. Among the economic groups affected by nuclear power, the electric utilities and equipment manufacturers are glad to have the Government provide the cost of research and development which will eventually lead to a technology usable by them. The advocates of public power are pleased to have atomic power technology remain in government hands so that their rivals in the private-power field cannot get ahead of them and freeze them out of the new field. Liberal and labor groups who hope for a government-operated atomic power system share this view. Finally, the armed services believe that atomic power reactors for military propulsion are amply provided for and generally favor the development of civilian power as a complementary program. With such wide support, the Commission seems likely to move ahead at a rapid pace on its civilian reactor program. ${ }^{5}$

\section{Utillzation of Resources: Mrlitary v. Civilian}

The fact that civilian atomic power had its inception primarily in a military program brings up the issue of the allocation of resources between military and

\footnotetext{
${ }^{3}$ Joint Committee on Atomic Energy, Current Statement of the Atomic Energy Commission on the Five-Year Reactor Development Program, 84th Cong., Ist Sess. I (x955).

Hearings, supra note 2 , pt. 3, at $475-76$.

"For a detailed exposition of the attitudes of these various groups towards the AEC's reactor program, see Hearings before the Joint Committee on Atomic Energy on S. 3323 and H.R. 8862, to Amend the Atomic Energy Act of 1946, 83 d Cong., $2 \mathrm{~d}$ Sess., pts. I and 2 (1954).
} 
civilian uses for atomic power. In general, as already stated, the position of the military is that civilian applications are not competing with military. Thus, Department of Defense representatives have stated that they strongly support developing the peacetime uses of atomic energy and broadening the scope of industrial participation. Although agreement has been reached in principle, this does not mean that the military interest will not be asserted where a scarcity of resources requires a choice between military and civilian application. And when a threat to the military program arises, the military has powerful spokesmen in the Joint Committee on Atomc Energy, where six of the nine House members serve also on the Committee on Military Affairs.

One military-civilian conflict arose in early r955 over President Eisenhower's proposal for the immediate construction of an atomic-powered merchant ship with a reactor like that of the Nautilus. Among those elements most active in support of this proposal were the Merchant Marine and Fisheries Committee in the House and the Interstate and Foreign Commerce Committee in the Senate. ${ }^{7}$ Arguments based on the propaganda war with the Soviet Union were brought up, and it was asserted that unless we acted promptly, the Russians might "beat us to the punch." Further, AEC Commissioner Libby asserted that the peace ship would not be built "at the expense of submarines, or the airplane, or any of the military programs." Admiral Rickover, the Chief of the AEC's Naval Reactor Branch, however, expressed the view that the merchant ship would result in the delay of the navy program, and painting a pessimistic picture of any kind of merchant ship program, he urged, instead, the development of a large ship reactor prototype, which would be of subsequent use in merchant vessels. ${ }^{8}$ After considering the question, the Joint Committee, apparently fearing a drain of resources away from experiments on military propulsion reactors if the plan were carried out, voted not to authorize the peace ship. ${ }^{9}$

What of civilian central-station power reactors? Basically they too are in competition for resources with military propulsion reactors. Although central-station reactors are simpler in design than ship propulsion reactors because they do not involve weight and size limitations and other special features, they use the same materials and are based on the same technology, which puts them in competition for the limited number of trained technical personnel. In this case, as with propulsion reactors, the forces pressing for civilian power are strengthened by the growing importance of the atom in foreign policy, which tends to suppress the doubts of the military

${ }^{\circ}$ See id., pt. 2 , at 733 .

${ }^{7}$ Representative Herbert C. Bonner (D., N.C.) and Senator Warren G. Magnuson (D., Wash.) are the respective chairmen of these committes, and they led the fight for authorization of an experimental atomic-powered merchant ship. See, for example, Senator Magnuson's statement, ror Cono. Rec. 8920 (daily ed. July 13, I955).

8 This discussion of the peace-ship proposal is found in Hearings before the Stubommittee on Autharizing Legislation of the Joint Committee on Atomic Energy, 84th Cong., 1st Sess. 78-92, $118-21$ (1955).

${ }^{8}$ See rox Cong. Rec. $7944-46$ (daily ed. June 27,1955 ). 
point of view. The cold war must be waged, it is argued, at the same time that preparations are made for the strongest possible defense in case a hot war should develop.

There remains, then, a clear potential rivalry between the military reactor program and both civilian propulsion reactors and central-station power reactors. The clash of interests results from a competition in the Government's program for priority to employ the limited number of contractors and technicians capable of doing this work. Although there appears to be general agreement that a civilian program is necessary, disputes such as that over the merchant ship may continue to arise as both the military and civilian programs are pushed rapidly forward.

The AEC Production Program and Civilian Power

The production of fissionable materials is the prerequisite for work in all phases of atomic energy. Two roads, both of which have been used by the Government since I945, lead to production of these materials. One is the separation process in which the fissionable isotope, U-235, is taken out of the stable form, U-238, in a gaseous diffusion plant. The other is the conversion of a blanket of U-238 into fissionable plutonium ( $\mathrm{Pu}-239)$, or a blanket of thorium ( $\mathrm{Th}-232)$ into the fissionable uranium isotope, $U_{-233}$. This is done in a converter reactor in which the neutrons given off in the fission process are used to transmute nonfissionable materials into fissionable materials, some of which, by a chemical separation process, may then be extracted for further use.

Much thought has been given to a program which would permit the use of the heat generated in a production reactor in the latter process for transformation into power. Thus, a converter or a breeder reactor could produce power as well as fissionable materials. This possibility, however, poses many problems. Naturally, the technology to support this "dual-purpose reactor" is much more complicated than that required to concentrate on materials or power alone. Aside from this engineering difficulty, there are policy issues to resolve. Should the Government buy up privately produced fissionable materials at a price guaranteed for a long period? Without such a guarantee, private industry would be unwilling to build and operate power reactors which are not economically practical for their power production alone. Would encouragement to enter into atomic power on this subsidized basis not slow down the attainment of economically practical power? Is the need for weapons-grade plutonium unlimited; and if not, should the Government pay the "military value" for plutonium or merely the "fuel value" which it would have if it were to be used in another reactor?

Although these and related questions have caused considerable debate in hearings of the Joint Committee, they have, as we have seen, been generally resolved by the decision that the Government should not encourage public utilities to produce atomic power by means of guarantees of high prices for the produced fissionable materials. In this, the United States has parted company with Great Britain. The British 
reactor program has been "largely slanted toward the breeding of other fissionable fuels, in addition to the production of power." 10

It is not the purpose of this article to set forth the arguments on both sides of this issue. Both appear to have solid reasoning behind them. The pertinent question is: how has public control operated so that those who opposed long-term subsidized plutonium prices have carried the day?

The opening of the policy debate can be attributed to a speech by Charles A. Thomas, President of Monsanto Chemical Company, on June II, I950. ${ }^{11}$ His proposal was for industry to own and operate a duel-purpose reactor, with the Government making it attractive by giving participating companies long-term contracts to purchase plutonium and by-products so that their capital could be amortized. This was followed by a similar recommendation from former AEC Chairman David E. Lilienthal, who took the same position in a Collier's article in July 1950. ${ }^{12}$ Out of this ferment came the proposal of the Detroit Edison Company and the Dow Chem. ical Company to be permitted to undertake a study of stationary nuclear reactors. ${ }^{13}$ And in January I95I, the AEC announced its Industrial Participation Study Program, in which private business could be cleared to investigate atomic power technology. ${ }^{14}$

During 1952, the Commission continued to arouse interest in industrial participation, and the dual-purpose reactor was mentioned frequently as a fitting incentive. Meanwhile, however, the Commission's own reactor development program was proceeding apace, its technological knowledge was growing, and it was following a program of expansion of its facilities for production of fissionable materials, the biggest increase in which was to be reflected in the appropriations bill in the summer of 1952. This expansion program, it was determined, was to be for materials production only, and, in a sense, this policy decision partly foreclosed a combined power and production program that might have been adopted instead.

Industry, however, continued to consider variations on the dual-purpose theme. In the fall of I952, Walker Cisler, President of Detroit Edison, articulated the view of one prominent utility group in a speech before the National Industrial Conference Board. ${ }^{15}$ He did not feel that it was necessary to establish a price for the atomic by-products as an incentive for private capital to build and operate commercial-sized nuclear power plants. Nor did he think that a market for the materials would be lacking. And the proposal submitted subsequently by the Dow-Detroit Edison group included selling plutonium to the Government but also stressed that such material had a prospective market for reactors to propel ships, submarines, and aircraft.

${ }^{20}$ Hearings before the Subcommittee of the Senate Committec on Appropriations on H.R. 6766, Public Works Appropriations, 1956, 84th Cong., Ist Sess. 15 (1955).

${ }^{11}$ The pertinent portions of this address and the text of the Monsanto proposal are reprinted in Joint Committee on Atomic Energy, Atomic Power and Private Enterprise, 82d Cong., 2d Scss. 277-80 (1952).

${ }^{22}$ See id. at $285-9$ r.

${ }^{14}$ See id. at 297-30r.

${ }^{13}$ See id. at $296-97$.

${ }^{15}$ See id. at $365-70$. 
At the same time, inside the Commission, a clearer policy line seemed to be taking shape on the dual-purpose reactor. It was that the Government could not afford to guarantee a plutonium market to builders of industrial reactors. The AEC saw the problems incorporated in the question of whom to let into the guaranteed and subsidized price program and whom to leave out. The long-term guarantee of prices for materials produced in what would probably be obsolescent plants also gave them reason to hesitate to make such commitments. ${ }^{\mathbf{1 6}}$

Against this background, in the fall of 1952 , the Joint Committee staff members undertook a general survey of the thinking of business and scientific communities regarding atomic power. ${ }^{17}$ It became evident that there was a divergence of viewpoint among the three chiefly-concerned businesses. Electric utilities were determined to enter more boldly into atomic power than they had done in the case of hydro-electric power, but they were not eager to be tied to a government market. Equipment manufacturers, like General Electric, Westinghouse, and Allis-Chalmers, were interested in the rapid development of power reactors by any route, whether subsidized by government purchase of fissionable materials or not. They saw in atomic energy a potential low-cost fuel to keep power costs low and power consumption rising. Lastly, chemical companies proved to be more interested in manufacturing fissionable materials and in developing extensive uses of fission products than they were in atomic power per se.

Further, at the hearings called by the Joint Committee in 1953 , the concensus of the witnesses was that the difficulties in designing economically practical power plants were largely technical. Consequently, there was a strong incentive to concentrate on "power-only" reactors in order to simplify the technology. A general "shying away" from subsidy in the form of high plutonium prices was noticeable. ${ }^{18}$

Nevertheless, in the 1954 hearings on the new act, the AEC still gave evidence of wanting to keep all approaches open. ${ }^{19}$ Its statements purposely kept the possibility of high prices for plutonium in the picture, but no commitments to a definite policy were made. Representatives Holifield and Price, however, saw in the combination of government ownership of special nuclear materials and a provision for a 40-year production facility license the likelihood of hidden subsidies to dual-purpose reactor operators. Although they persuaded the Joint Committee to limit any guaranteed fair price to seven years, they saw in the AEC's discretion to set these prices the possibility of subsidies of undetermined magnitude. ${ }^{20}$ Labor union repre-

${ }^{10}$ On the AEC's thinking at this time, see an address by Commissioner Zuckert, delivered before the Chicago Section of the American Chemical Society, AEC Release, Sept. II, I952. The Commissioner posed some of the difficult problems involved in the dual-purpose approach and suggested that "power-only" reactors might possibly be the solution.

${ }^{17}$ See Atomic Power and Private Enterprise, supra note $\mathrm{II}$, at 33-56.

${ }^{18}$ See Joint Committee on Atomic Energy, Summary of the Hearing before the Joint Committee on Atomic Energy, 83d Cong., Ist Sess. 4-9 (1953).

${ }^{10}$ See Hearings, supra note 5 , pt. 2, at 570-7x.

${ }^{20}$ See Joint Committee on Atomic Energy, Report to accompany H.R. 9757, Amending the Atomic Energy Act of 1946, as amended, and for Other Purposes, H.R. REP. No. 2181, 83d Cong., 2d Sess. r30-3I (I954). 
sentatives, desiring government ownership of reactors, were also opposed to subsidizing private reactors by high prices for their production of fissionable materials. ${ }^{21}$ The utilities, too, were decidedly cautious concerning the pricing section. Walker Cisler, of Detroit Edison, repeated his preference to have the utilities free to dispose of the material as they wished rather than be tied to a government market. ${ }^{22}$ And others pointed out the danger of retarding the reactor program as a result of the Commission's reluctance to license reactors because it would thereby incur large obligations to purchase special nuclear material. ${ }^{23}$ Only General Electric and the private laboratories felt that purchase by the Government was desirable and suggested that the AEC should contract for special nuclear materials at firm prices and thus provide a strong incentive for private investment in dual-purpose reactors. ${ }^{24}$

The passage of the act left the Commission free to decide the issue. Its secret price lists were announced in January 1955. As later interpreted, these were based on a policy of a "power-only" reactor, since the by-product fissionable material was to be priced, in the long run, as reactor fuel rather than for weapons purposes. AEC spokesmen have explained the decision as based on (I) technical contradictions and (2) the problem of fitting together power supply and plutonium supply. ${ }^{25}$ The Commission had decided that the dual-purpose route simply was not one which by itself would lead to economic atomic power. If the AEC had "up its sleeve" a 2oth century Homestead Act to encourage pioneering in nuclear power plants, at least it was not going to exercise its prerogatives by means of high prices for fissionable materials.

As a result of this policy, it was not possible for private investment alone to finance and construct atomic reactors, supported by high prices to be paid by the Government for materials produced. Instead, a period of joint undertakings became necessary, a period of cooperative government-industry work toward achieving competitive "power-only" plants.

\section{The Integration of Government and Business}

When the Government carries out a program of power reactor research and development by means of contracts, the question of the extent of the government effort is resolved in terms of appropriations. But when a jointly financed undertaking is planned, the problem of how-and where-to draw the line between government aid and business expense becomes a complicated policy issue.

The rationale of government aid is important. It is justified because of private contributions to national defense. Rapid tax amortization and direct government financing at low interest rates are cases in point. The Duquesne Light Company has applied for this aid for its power plant being built at Shippingport, Pennsylvania,

${ }^{21}$ See Hearings, supra note 5, pt. I, at 486-5I 4 (I954).

${ }^{22}$ See id. at 76-77.

${ }^{23}$ See $i d$. at $377-98$.

${ }^{24}$ See $i d$. at 349,428 .

${ }^{25}$ For a discussion of AEC thinking on this matter, see Power Reactor Development in the United States, an address delivered before the Canadian Electrical Association by W. Kenncth Davis, Director, Division of Reactor Development, AEC Release, June 29, 1955. 
in connection with the AEC's pressurized water reactor. ${ }^{26}$ Government aid is also justified as paying for knowledge which will generally advance a technological art in the public interest. The National Advisory Committee for Aeronautics operates on this rationale, and the AEC's reactor demonstration program has the same basing.

What forms should AEC aid take? The Commission has announced its policy: not to "hide a large part of this [aid] in the price paid for materials which will be produced by these reactors" but rather "to bring it out in the open where it is a clear-cut research and development assistance."27 This thus rules out the possibility of setting the secret prices for privately produced fissionable materials much higher than the materials really cost to produce. In addition, the AEC announced that it would charge private firms for materials "burned-up" or lost, and that it would charge the full costs of fuel fabrication and chemical processing, two services to be performed for industry by the Government. ${ }^{28}$

The AEC did, however, make available three types of aid: ${ }^{29}$

... waiver of the charge that the licensee would otherwise have to pay for the use of special nuclear material furnished by AEC; performance in AEC laboratories and test facilities without charge to licensees of certain mutually agreed upon research and development work; and financial assistance under appropriate research and development contracts.

This assistance could be arranged to suit the private firm's need in each undertaking approved under the AEC's Power Reactor Demonstration Program, in which the Commission asked for industry proposals on constructing power reactors under license and indicated that those receiving the least amount of government aid would have a greater chance of acceptance. Clearly, this aid was to be tailored to the need of each reactor project. The AEC, as we have seen, has described it as "clearcut research and development assistance." Provided the dollar equivalents of the services made available by the AEC to each project are made known, this aid will be open and not hidden. Yet, because it will differ in each case, it will be hard to explain why a greater private share could not have been bargained out in each case.

The policy of giving this form of aid is by no means a settled one. There was controversy over the decision to tie in research and development contracts with licenses to construct and operate civilian power plants. In fact, some doubt is cast on the legality of this scheme by the 1954 act's section 169 , which prohibits funds from being employed in the construction or operation of licensed facilities except under research and development contracts or agreements. ${ }^{30}$ Representative Cole took issue with the AEC; he interpreted the provision-in keeping with the legislative history, he said-to allow the Commission to pay for research work only after

${ }^{20}$ See Hearings, supra note 2, pt. I, at 90-10I.

${ }^{37} 1 d$. at 169 .

${ }^{28}$ See $i d$. at $74-75$, r 80 .

${ }^{20} \mathrm{Id}$, at 152 .

${ }^{30}$ The text of this section is as follows: "No funds of the Commission shall be employed in the construction or operation of facilities licensed under section 103 or 104 , except under contract or other arrangement entered into pursuant to section 3x..." 68 STAT. 952, 42 U.S.C.A. \$2209 (Supp. I954). 
private facilities were built. Senator Anderson also exhibited uneasiness about this kind of aid or subsidy. However, other Joint Committee members defended the AEC's judgment in proposing the scheme. ${ }^{31}$

Later, at the hearings in May 1955, Representative Holifield and Joint Committee Staff Member Walter Hamilton developed the interpretation that judgment must be made, in each case, whether the research assistance results in greater benefit to the technological art or to the individual company. At this hearing, the AEC offered its solution to the problem-interpreting section 169 to prevent the Government from giving away title to any part of a reactor (bricks or mortar) built by the Government as research assistance. ${ }^{32}$

Aside from this issue of legality, Representative Durham was not satisfied with the idea of a different amount of government aid in each case. Recognizing that favoritism and special treatment for different industrial firms or regions of the country must be avoided if possible, he desired a formula from which to derive the amount of money the federal government would put up for each project combining business and federal funds. His idea was to have a fixed percentage-say 25 per cent -so that a firm in one region would get the same treatment as one in another. But the AEC immediately pointed out the impossibility of this by citing the example of the need for a demonstraton homogeneous reactor. Since no industry proposal for one had been made, the Government had to be free to arrange a higher contribution to induce some firm to contribute some of its own money. ${ }^{33}$

A related problem arises out of the fact that the introduction of private money into reactor work may become such a goal in itself that it may be furthered at the cost of the government program. For example, the House Appropriations Committeemen, in July 1955, eliminated money for the Power Reactor Acceleration Program. They did so because the program was not spelled out in the justifications, but they could easily have taken up the argument that the public money should be shut off in order to encourage more private money to be invested. Specifically, Representative Holifield cautioned the AEC against warping the program just because it wanted to get a private firm to operate the Engineering Test Reactor. He counseled: "... do not worship the fetish of getting outside money in, to the point where you do it at the long-term detriment of the Government. ..."34

All in all, the dividing line is not clear-cut, and charges of "give-away" haunt anyone who embarks on one of these combined programs. The lag in announcing arrangements under the Power Demonstration Reactor Program was probably due in part to complications of this nature. Understandably, the Commission was careful about entering into commitments of this kind as the present transitional period

\footnotetext{
${ }^{31}$ For this debate, see Hearings, supra note 2, pt. I, at 154-79.

${ }^{32}$ See Hearings, supra note 8, at 49-57. This AEC formula was subsequently adopted. Sce The Power Demonstration Reactor Program, remarks prepared by Louis H. Roddis, Jr., Deputy Director, Division of Reactor Development, AEC Release, Sept. 27, 1955.

${ }^{33}$ See Hearings, supra note 8 , at $13-14$.

ss Id. at 106.
} 
involves it in a crossfire of views on the amount and kinds of government aid which it should dispense. The voices are rising from every quarter of the domestic scene. The announcements by the Russians at Geneva that they have found economically practical atomic power will increase the clamor for rapid development and government aid. At the same time, the voices of caution and restraint against pampering American industry will not be silenced. The AEC will find its decisions becoming progressively more subject to the conflicting influences of public opinion.

\section{Quick Development by "Insiders" and Potential Monopolists}

\section{v. Controlled and Equal Access}

The incipient atomic power industry consists in part of equipment manufacturers who will be in the business of building and selling reactors and components. Several giant firms, such as General Electric, Westinghouse, and Allis-Chalmers, lead the field. These companies have been principal contractors and subcontractors of the AEC, chosen because they have been judged to possess the industrial capacity to provide the best management for AEC facilities. As a result, they are at great advantage over other companies. They have acquired technically trained staffs and valuable experience in solving reactor problems.

The economic organization of American industry is, thus, brought into the picture. A question arises: should the results of government research and development be exploited by the small group of large industrial firms, or should the benefits of government discovery be widely distributed? Put in these terms, an affirmative answer to the latter question becomes the rallying cry of liberals.

A conflict of objectives of public policy is involved here. A quick exploitation by private enterprise would be achieved by letting the competitive position of these firms determine the outcome of their economic rivalry. Yet, a public policy of distributing the benefits of the new technology broadly would require a positive governmental program to aid other firms to move into the business and, at the same time, to restrain those with a "head-start." The AEC has attempted to expand the group of knowledgeable firms. The study agreement program was for that purpose. The hiring of new contractors for the AEC's five-year power reactor program, such as North American Aviation, has had the same end. The letting of the contract to Westinghouse for the 60,000 kilowatt pressurized water reactor power plant ignored this policy, but the AEC explained that very few companies were able to do this job at all because of insufficient access to technical knowledge. ${ }^{35}$ And the invitations for bids on the power-package reactor provided another opportunity to bring new firms into the atomic power business.

On what basis to make the awards has created a problem. If the bids which are most economical for the Government are accepted, these are likely to come from

\footnotetext{
${ }^{35}$ Similarly, Westinghouse and General Electric held all contracts in the naval reactor development program until a contract for a small submarine reactor was awarded to Combustion Engineering, Inc., in August 1955. See AEC Release No. 677, Aug. II, 1955.
} 
the firms with the most experience, money, and assets-and the policy of distributing widely the know-how developed by tax dollars will be thwarted. On the other hand, if bids from inexperienced companies are accepted, no firm assurance of their competency to do the work efficiently is present, especially since they will probably not be able to outbid the experienced firms for the few technicians available. Hence, without an aggressive governmental policy to spread the benefits at the cost of quick private development, the large equipment manufacturers have a good chance of gaining a great share of the new market.

The issue of market leadership also involves the matter of patents, for it has been the patented processes which held the market for the two or three big concerns in electric generating equipment. At the hearings on amending the Atomic Energy Act, business interests presented a solid front for firmer patent rights in inventions. ${ }^{30}$ Opposed, however, was an underlying fear in Congress lest the advantage now held by a few companies already engaged in atomic energy work (principally AEC contractors) would give these companies an unfair advantage over competitors, and even a dominant position and accompanying monopoly. As a result, provisions to prevent insiders from converting their advantage into a monopoly were written into the bill. One was the so-called compulsory patent licensing (operable until September I, I959), by which the AEC, after satisfying a great array of conditions, can require a patent holder to license another firm. ${ }^{37}$ The other was a provision which gives the AEC title to any invention conceived in the course of any contract, arrangement, or relationship with the $\mathrm{AEC}$, regardless of whether funds of the $\mathrm{AEC}$ are involved, although the Commission has the power to waive such claim. ${ }^{38}$ Thus, as long as the AEC continues a tight policy on releasing inventions for private firms to patent, the threat of advantaging "insiders" appears to have been defeated. Pressures will, of course, be directed at the AEC, in whose discretion the patent policy now falls, but the threat of a charge of "give-away" hangs over the Commission's head and serves as an impediment to sweeping waivers of any kind.

The chemical firms were also much concerned that patents be allowable in atomic energy work. However, since the AEC has followed a policy to the effect that all chemical processing will be done for some time by the Government under contract, the chances for these firms to be in a position to obtain patents is remote.

Because of the general congressional concern lest monopoly find a suitable breeding ground in atomic energy, no special dispensations with respect to the operation of the federal antitrust machinery were inserted in the 1954 act-in fact, it is explicitly stated that the antitrust laws are applicable to all licensees. Furthermore, the AEC must report promptly to the Attorney General any conditions which appear to tend

\footnotetext{
${ }^{36}$ See Hearings, supra note 5, pt. 1, especially the testimony of Babcock and Wilcox Co., at 92, Dow Chemical Co., at 104, and General Electric Co., at 334 .

37 \$153. 68 STAT. 945, 42 U.S.C.A. \$2183 (Supp. 1954).

${ }^{38} \$ 152.68$ STAT. 944,42 U.S.C.A. $\$ 2182$ (Supp. 1954). These and cognate patent problems are discussed more fully in another article in this symposium. See Boskey, Some Patent Aspects of Alomic Power Development, infra, I13-31.
} 
toward the violation of these laws. And before a competitive license can be issued, the Attorney General is to advise the AEC publicly whether the proposed license tends to "maintain or create a situation inconsistent with the antitrust laws." 39

The risk-dividing way to share the burden of development in this new field, however, is by means of groups of companies. Study groups are on this basis, and presumably power reactors will be feasible for several power companies banded together. Accordingly, conflicts with the Public Utility Holding Company Act and the antitrust acts may possibly arise. To obviate any difficulty in this connection, therefore, the Detroit Edison group has formed a nonprofit corporation for its proposal to build an experimental prototype of a breeder reactor. ${ }^{40}$

In addition to the combination of public utilities alone, there was also the distinct possibility of a vertical industral organization, a type of combination which had encountered difficulty with the antitrust laws in the past. By this means, a single business could produce power in a dual-purpose reactor, chemically separate fissionable materials from the reactor core, and convert the by-product materials to chemical uses of various kinds. The Dow Chemical Company in the Detroit Edison group offered the opportunity for such a vertical combination. However, when the AEC's policy of not underwriting high-priced plutonium production and of not relinquishing chemical processing to private enterprise became apparent, the Dow Chemical Company withdrew from this group. ${ }^{41}$

Regardless of its legality under existing law, affiliation of private power companies is feared as monopoly in many quarters. These combinations are considered to be a threat by those who believe in public power and its yardstick as the only effective form of competition in the electric power industry. This viewpoint was strongly expressed in the Interim Report on hearings on monopoly in the power industry, held in 1953 and 1954 by Senator Langer's Subcommittee on Antitrust and Monopoly Legislation. The Subcommittee expressed the gravest concern over a new "surge of monopoly" in the power industry. It found, first, "that there is a two-pronged drive by private monopoly to destroy public competition in the power business"; and second, "that Wall Street domination of the power industry has revived many of the holding company evils which Congress sought by legislation to suppress, particularly the extension of monopoly control over very wide regions." ${ }^{32}$ The pattern of abuse by private utilities, said the Subcommittee, ${ }^{43}$

... indicates the difficulties, and often impossibilities, of effective State regulation.... The hearings further developed alarming evidences of the failure of the Public Utility Holding Company Act to accomplish its purpose, e.g., to protect the public against the domination of operating companies by holding companies, excessive service charges, and all the monopolistic devices which tend to increase rates and restrict service.

${ }^{30}$ \$105. 68 STAT. 938, 42 U.S.C.A. \$2135 (Supp. 1954).

${ }^{10}$ See Hearings, supra note 2, pt. 2, at 236-37, 252-53.

¿2 See id. at 243.

"Senate Committee on the Judiciary, Interim Report, Monopoly in the Power Industry, $83 \mathrm{~d}$ Cong., 2d Sess. 4 (1954).

${ }^{6}$ Id. at 7 . 
The Subcommittee indicated its view that the Republican administration had aided this dangerous trend toward the destruction of competition by a repudiation of the all-important "antimonopoly instrument of democracy," the yardstick.

Much of this desire to prevent monopoly of any kind in the atomic power industry rallied around an insistence upon retaining section $7(b)$ of the McMahon Act. ${ }^{44}$ Briefly, this provision required the Commission to report to the President if and when it believed any industrial, commercial, or other nonmilitary use of fissionable material had been sufficiently developed to be of practical value. In the report, the Commission had to estimate the economic, political, and social ramifications of such developments. The President then submitted it and his own recommendations to Congress. Until ninety days had elapsed, no license could be issued. This procedure was taken as insurance that the atomic industry could not be born to monopoly without a full open dicussion under the winds of public opinion. Labor unions supported this view, and found another reason for such a report in the danger of technological replacement of workers in the coal and oil industries. ${ }^{45}$ Contrariwise, advocates of quick assumption of responsibility by private enterprise were unalterably opposed to the section 7 (b) report. David E. Lilienthal sharply criticized the report as applying a brake on progress, because all groups opposed to the growth of an atomic energy industry could unite in lobbying Congress to stall the industrial development of civilian atomic power. ${ }^{46}$ In various stages of the 1954 act, the provision was successively weakened until it required merely a finding in writing by the Commission alone before it could issue competitive commercial licenses under section I03. ${ }^{47}$ As these will not be feasible for some time, the report is of small significance at present. Meanwhile, however, by means of the gradual private assumption of responsibility, aided by $A E C$ research and development contracts, the framework of the atomic power industry in great measure will have taken shape before issuance of the requisite "finding of practical value."

Still another aspect of the competitive position of industry involves public policy. Business firms working for the Commission could attempt to exert influence in behalf of policies designed to improve their relative standing vis-à-vis their competitors. The Joint Committee recently has evinced a suspicion of this. Concerning General Electric's recommendation of a high pressure water design for the submarine advanced reactor, it raised the question whether the company urged this type so as to catch up with Westinghouse, which had had all previous experience in this field. ${ }^{48}$

46 ST STAT. 764, 42 U.S.C. $\$ 1807$ (b) (r946).

${ }^{25}$ Mr. Andrew J. Biemiller, member of the National Legislative Committee, AFL, advocated retention of the $\$ 7(b)$ report in the hearings on the amendment of the 1946 act in May 1954. Sec Hearings, supra note 5, pt. I, at $27 \mathrm{I}$. And at the first hearings subsequent to the passage of the ncw act, he reiterated this suggestion. See Hearings, supra note 2, pt. 2, at 325, 327. Sec also the letter from Anthony Matz, International President of the International Brotherhood of Fireman and Oilers, $i d$., pt. 3 , at 588 .

${ }^{10}$ See note 12 supra.

${ }^{47}$ \$102. 68 STAT. 936,42 U.S.C.A. \$2132 (Supp. 1954).

${ }^{48}$ See Hearings, supra note 8, at 68-69. 
Concern over the likelihood of creating a monopoly in the atomic energy industry is pronounced in the speeches and testimony of labor and public-power advocates. Several of the liberal Congressmen have joined them. On the whole, however, these pressures have not been strong enough to instigate precautionary measures of any consequence for the AEC.

\section{Regional Interests v. Economic Progress}

The prospects of atomic power have excited regional interests. The coal-mining areas have been represented by the National Coal Association and the miners' unions. The Coal Association urged that if government subsidization of the construction or operation of full-scale permanent nuclear power plants were deemed necessary, these facilities should be built outside of coal's normal market areas. The coal industry, its spokesman said, feels it is entitled to ask that taxpayers' money not be used to subsidize its competition. The unions held that the exploitation of nuclear power should be done by the Government for the high-cost power areas. Congressmen from Pennsylvania have reportedly questioned the location of the PWR in that state. $^{49}$

On the other hand, high-cost power areas asked for government-generated nuclear power. A proposal from Nevada interests for nuclear power for mining and irrigation was put forward. ${ }^{50}$ But since the prevailing policy was to turn to private business to finance in great part the full-scale prototypes of nuclear power plants, this proposal fell on barren ground. In Minnesota, likewise, political pressure arose for government help for a rural electric atomic power plant. $^{51}$ However, the REA, in a Republican administration committed to curtail expansion of public power, was not in a position to be very active in such gathering pressure. It is questionable whether sufficient momentum can be gained in these areas to enlist a disinterested AEC in helping work out the technical and financial details of such projects. The easiest course is to rely on the large utility groups, which, because they are technically experienced and financially backed, can carry forward reactor projects with the minimum of guidance from the AEC.

These groups are headed by the large power companies of several metropolitan areas. Consolidated Edison of New York was first to make a straight noncompetitive license application; Detroit Edison and Commonwealth Edison of Chicago were the first to gain AEC acceptance of their proposals under the Power Demonstration Reactor Program. ${ }^{52}$ Clearly, the large cities are going to have atomic power

${ }^{40}$ The point of view of the coal-mining regions was expressed to the Joint Committee by spokesmen for the National Coal Association. See Hearings, supra note 2, pt. 3, at 475-87.

${ }^{60}$ See Atomic Power and Private Enterprise, stipra note II, at 23-24.

62 The proposal for such a plant is reported in N.Y. Times, Aug. 9, r955, p. 8, col. 2.

${ }^{6}$ See AEC Authorizes Action Toward New Nuclear Power Reactors, AEC Release No. 674, Aug. 8, 1955. Although the Commonwealth Edison group was apparently responding to the AEC's Demonstration Reactor Program, it matched Consolidated Edison in proposing to bear the total cost of its nuclear plant, as the New York utility had done. Similarly, Commonwealth Edison requested a licensing arrangement for its plant. 
first, although the policy intent of the 1954 act appeared to favor the high-cost power areas. $^{53}$

\section{Private Power v. Public Power}

The prospect of a major new source of electric energy has set the forces of private power jockeying for position against the forces of public power. In the background of this rivalry over the atom is the history of hydro-electric power generation. The possibility of harnessing falling water to produce power was neglected by private power groups, with the result that the federal government moved in to construct dams and central-station generating plants. The power generated was given on a preferred basis to public corporations, which distributed it in cities and rural power districts. The federal government also encouraged these public bodies by loans to build up their distribution systems. In addition, federal power policy incorporated the idea of preference for public bodies in securing licenses for hydro-electric generation in case the federal government itself did not use the falling water.

The concept of water in streams as a natural resource of the federal government, to be used for the citizens of the area without including a profit for the shareholders of a private corporation, thus, became the creed of the liberal thought of the Western states. Federal sale of hydro-electric power at rates below those charged by the private companies of the area became another rallying cry. Known as the "yardstick" device, it was looked upon as the only effective way of preventing private power companies from taking advantage of the natural situation of one distributor for one geographic area. It was alleged that state regulatory commissions were largely ineffective in bringing down electric rates consistent with technological improvements in power production. ${ }^{54}$

As it became obvious that the future would see practical atomic power, the private power companies determined that they would not be "caught napping" as they had been in the development of hydro-electric power. They recognized that the climate of opinion was running against public power for the first time since the advent of the New Deal, and they saw a chance to keep the federal government out of nuclear power generation. They had added incentive, in that they faced a future in which conventional sources of power were becoming exhausted or excessively costly. This prospect lent a note of urgency to the development of practical atomic power.

As a result, private power has not waited for completely competitive nuclear power before spending its own money. Because large sums were required for research and development and for capitalization of future power plants, private power companies formed associations to share costs and applied for study agreements with the AEC. In this way, they could familiarize their technicians with reactor tech-

${ }^{63}$ The intent was stated specifically with respect to commercial licenses granted under $\$ 103$. See $\$ 182$ (c), 68 STAT. 954, 42 U.S.C.A. \$2232(c) (Supp. т954).

" For a concise treatment of the evolution of government power policies, see King, Pouver Policy, in 2 Editorial Research Reports 465, especially 469-76 (1953). 
nology and acquire the knowledge needed for the next stage, i.e., actual work on developmental projects. Two groups, the Pacific Northwest Power Group and the Rocky Mountain Nuclear Power Study Group, were organized by the private power companies in areas of the West which had been thoroughly invaded by public power. In addition to this study group activity, the biggest private utilities in the large urban areas seem to be eager to participate actively in building full-scale prototype nuclear plants, as indicated by their proposals under the Power Demonstration Reactor Program.

To public-power advocates, private development of atomic power is unfortunate. In reference to the formation of the Rocky Mountain study group of private power companies, Senator Anderson of the Joint Committee suggested the public-power viewpoint when he said: ${ }^{55}$

The announcement that Electric Bond and Share would be the principal genius in trying to bring nuclear power to the Rocky Mountain States puts a cold shiver down the back of any person who is hopeful that we may get development in that part of the world.

Those who advocate public power realize that a continuation of the AEC in the civilian power area would be the best guarantee against private power preempting the field. They favor a kind of section 7 (b) report on which open political forces can play in their behalf. They hope that a new "atomic TVA" can be formed to produce nuclear power and provide a governmental yardstick. Speaking chiefly through Representative Holifield on the Joint Committee, the public-power group sees a governmental obligation to distribute the benefits of federal research to help in reducing consumers' rates-a result which, it is alleged, will not occur if private power companies are allowed to pre-empt the new field.56 The group fears that private utilities will develop atomic power in low-cost areas and require rate-payers there to pay for the costs of development. On the other hand, the argument runs, if the Government conducts the development in high-cost areas, the lessons learned there can be used for all.

The public-power bodies, however, are definitely at a disadvantage to the private companies in research and development. Most of them are small, because they came into being to fill in the areas not covered by the big private utilities. They are dependent on local approval for investment in experimental work. Because of their small capitalization, it is difficult for them to perform research and development work. This latter problem came up at the hearings on the confirmation of Dr. Libby as Atomic Energy Commissioner. The National Rural Electric Cooperative Association, using Senator Anderson as its spokesman during the hearings, asked Dr. Libby: "Do you feel the chief criterion of cooperation between AEC and these public groups should be the amount of money that a group can put up?"57 Dr.

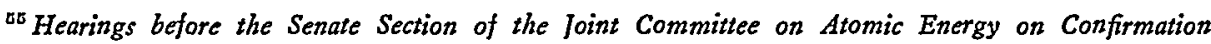
of AEC Commissioners, June 1953 to March 1955, 84th Cong., Ist Sess. I7 (x955).

${ }^{60}$ The approach taken by Mr. Holifield is illustrated by two lengthy statements which he made on the floor of the House of Representatives. 100 Cong. REc. 2437-40, 5598-600 (I954).

${ }^{\mathrm{I}}$ See Hearings, supra note 55 , at $\mathrm{I7}$.
} 
Libby replied that it was the competence of engineering staff which should govern, but he neglected to note that money can buy this talent. All in all, his reply hardly refuted those who argue that the public groups are, in fact, handicapped in their limited ability to obtain capital.

Still, public power is making a determined effort in the development of atomic energy, although it does not and probably cannot display the aggressiveness shown by the private companies. By mid-r955, four public bodies had entered into study agreements with the AEC: the TVA, the Seminole Electric Cooperative of Florida (a federation of five distributing cooperatives), the Consumers Public Power District of Nebraska, and the National Rural Electric Cooperative Association. Two proposals had been made for building medium or large-scale power plants. One proposal, from the Consumers Public Power District of Nebraska, came under the AEC's Power Demonstration Reactor Program. The other was a proposal from the Rural Cooperative Power Association of Elk River, Minnesota, to build a 22,000 kilowatt nuclear plant. ${ }^{58}$

These interests are aided by considerable public-power sentiment in Congress, though there is little in the AEC and the rest of the Executive Branch, as revealed by the Dixon-Yates controversy. When the new organic law for atomic energy was being written, the public-power advocates took advantage of their congressional support to insert clauses designed in their favor. The bill, as written by Representative Cole and Senator Hickenlooper, generally protected private business against publicpower corporations. It prevented the AEC from becoming a power producer except incidentally as a result of experimental research and development facilities. And although the bill was amended on the floor of the Senate to authorize the AEC or other federal agencies to generate power commercially and to market it through the Secretary of the Interior under the Flood Control Act of 1944, which gives preference to public bodies and cooperatives, this provision was defeated in conference. ${ }^{59}$

The first of two preference clauses was put into the act in section $44^{.00}$ This gives to public bodies and cooperatives preference in purchasing experimental and byproduct power from the AEC. The by-product power provision would be important only in case the Government should build large-scale dual-purpose reactors. The preference on experimental power has required the AEC to offer the power from the land-based prototype of the submarine intermediate reactor at West Milton, New York, to three public power bodies within a reasonable transmission radius. ${ }^{01}$

${ }^{6}$ The AEC rejected the Nebraska proposal in its August 8 release, stipra note 52, but subscquently approved a revised version as a basis for negotiation. See AEC Authorizes Reactor Power Plant Negotiations with Nebraska Power Group, AEC Release No. 723, Oct. 27, 1955. The Minnesota proposal had not then been acted upon.

50 The text of the provision-the so-called Johnson amendment-is printed in 100 CoNc. Rrc. II221 (1954). For the debate, see $i d$. at II221-37, II319-88.

${ }^{60} 68$ STAT. 929, 42 U.S.C.A. \$2064 (Supp. 1954).

${ }^{\text {ax }}$ See AEC Announces Plans for First Sale of Atomic-Electric Power, AEC Release No. 663, July 13, I955. 
Another preference clause involved the granting of commercial licenses to operate production or utilization facilities. In the bill, as reported out of committee, preference was to be given only to high-cost power areas in the United States. It was amended however, to include public bodies and cooperatives. And to assure that preference agencies and others will get a full opportunity to be heard on any interest they may have, the law requires that regulatory agencies and public and private utilities within transmission distance of a proposed reactor shall all receive notice before applications for commercial licenses are acted on. ${ }^{62}$ There is some doubt, however, about how useful this preference clause will be to the public-power groups, because they will not have the capital to put up when commercial licenses become feasible. Hence, one might expect them to prefer to have the federal government produce the power and wholesale it to them. ${ }^{83}$

Public and private-power groups are deeply entrenched in the fabric of American economic life. Their running and indecisive battle is destined to continue indefinitely. Atomic power, armed with the importance of its military and international aspect, will enter one of the most active battlefields of American politics. All concerned with it will find themselves involved in the struggle.

\section{Secrecy and Thermonuclear Power}

Atomic power from nuclear fission, we have seen, is becoming more widely understood and discussed. It is increasingly subject to most of the forces of democratic control. Atomic power from thermonuclear energy, however, was almost wholly hidden behind the barrier of secrecy until August 1955. At that time, Chairman Strauss, of the AEC, admitted to reporters in Geneva that the United States had been working on the subject for a considerable time. He said that scientific progress was being made, but that no real break-through had occurred. This was the first announcement made to the American people about a program that may turn out to have enormous importance. ${ }^{64}$

In the period preceding the Geneva conference, certain stirrings over the possibility of fusion power were noticeable, particularly from persons connected with the Joint Committee. The former counsel of the Committee, John S. Walker, wrote an article in which he stressed the potentialities of thermonuclear power and urged that a concentrated effort to achieve it should be made by the AEC, in a new lab-

${ }^{02}$ See $\$ \$ 182($ b), (c). 68 STAT. 954, 42 U.S.C.A. $\$ 2232$ (b), (c) (Supp. I954).

${ }^{6}$ On the comparatively unfavorable financial situation of the public power systems, see Hearings, supra note 2, pt. 2, at 412-13. Appended to the main issue over public versus private power is the question of who will pay for the costs of development by private power companies. The ratepayers and the stockholders are involved. How the burden will be shared-and how the expenses will be recoupedis a complicated subject beyond the scope of this paper. It partly depends on the rulings of state regulatory commissions in allowing developmental expenses as part of the deductible expenses in rate-making.

For a more extended discussion of the problems of public power in an atomic context, see Marks, Public Power and Atomic Power Development, infra, 132-47.

o* Chairman Strauss's revelations were made at a press conference held by the United States Delegation to the International Conference for the Peaceful Uses of Atomic Energy, at Geneva, Switzerland, on August Ir, 1955. See N.Y. Times, Aug. 12, I955, p. I, col. I. 
oratory divorced from nuclear weapons work. ${ }^{65}$ Chairman Anderson, of the Joint Committee, in a speech delivered shortly before the Geneva conference opened, made reference to the possibility of fusion power, and asked the dramatic question: "Will we be able to tell the world, at Geneva, whether we are trying our hardest to find out whether [the production of thermonuclear power] can be mastered?"00

The Joint Committee has always been among those most eager to see the greatest possible development of the military uses of thermonuclear energy, and Senator Anderson's remarks, together with prior references by other members, suggested that the Committee's stress on fusion carry over into the peacetime field. This was borne out by later statements from three Committee members, Senator Anderson and Representatives Price and Hinshaw, upon their return from Geneva. The three legislators suggested that the United States was "fumbling" in its program for fusion power, and revealed that the Committee had repeatedly urged the Commission to "put forth the maximum possible effort" in this significant area."

The AEC, however, has taken a limited approach to fusion power. Chairman Strauss said enough at Geneva to show that our program is clearly not an all-out effort. It is a "very long-range" program, he said, and on a moderate scale. He gave assurances that the work is not of such magnitude as to jeopardize the future of the strong program under way to achieve cheap fission power. ${ }^{68}$

It is clear that policy issues are buried here, perhaps issues of the greatest significance. It is equally clear that democratic public control is virtually impossible. The statements and allusions made thus far are extremely vague and uninformative. Chairman Strauss indicated certain policy decisions which had been made-e.g., that a program should be carried on, and that it should be only a small, long-range effort-but he gave outsiders no basis whatsoever for evaluating these decisions. No facts have been released on which an opinion can be built. It may be that such strict concealment is necessary, although former Commissioner Smyth has advocated outright lifting of the veil of secrecy in the thermonuclear field. ${ }^{60}$ In any case, democratic control under these conditions is severely handicapped. (1955).

${ }^{65}$ Walker, Thermonuclear Reactions: Can They Be Used for Man's Benefit?, 33 Foreign Afrains 605

${ }_{66}$ Address of Senator Clinton P. Anderson before the Summer Conference of the Advertising Executives' Association, Inc., Joint Committee on Atomic Energy Release, July 12, 1955.

${ }^{07}$ See N.Y. Times, Aug. 24, 1955, p. 6, col. 3. On August 25, 1955, Senator Anderson further suggested that the President himself issue "a public directive which would mobilize our scientific and industrial power behind an effort to achicve controlled thermonuclear reactions." Revealing that approximately $\$ 33,000,000$ was being spent in the controlled hydrogen field, the Senator also suggested that "we immediately step up the rate and scale of our spending on controlled hydrogen energy." The Businessman's Atom, address of Senator Clinton P. Anderson before the Cleveland Rotary Club, Joint Committee on Atomic Energy Release, Aug. 25, 1955.

${ }^{68}$ Press Conference, United States Delegation, International Conference for the Peaceful Uses of Atomic Energy, Geneva, Switzerland, Aug. Ir, x955. See N.Y. Times, Aug. 12, 1955, p. 1, col. x. A few more details were revealed in a subsequent press conference by Mr. Strauss. See N.Y. Times, Oct. 4, 1955, p. I, col. I. Entitled "Project Sherwood," the program was described in terms of the places and directors involved. The amount of money being spent was stated mercly as "significant."

${ }^{\circ 0}$ See speech before the National Industrial Conference Board, Oct. 28, 1955, excerpted in 2 Atomic Industrial Forum Memo 5 (Nov. 1955). 


\section{The State of Democratic Controls}

Atomic power presents the usual spate of issues for public policy. These bring into account the many objectives which American Government must simultaneously pursue. Decisions are required which necessarily make compromises between conflicting ends. Thus, specifically, if we take the road to maximum military use of atomic power, we may not be in a good position in the international rivalry of propaganda; but if we take the road of maximum civilian power, the military program could suffer from lack of technicians. If we subsidize private enterprise too greatly, industry will not have the incentive to develop competitive economic power; but if we fail to subsidize enough, our development may lag. If we keep down the government share by favoring those firms which can pay a larger share of the developmental expenses, we run the risk of allowing a few companies to fill the field; but if we insist upon equal access, we must hold back progress toward practical power. If we permit free development, we may suffer from the exacerbated hardships of technological change; but if we plan to soften the latter, we may slow the rate of economic progress. If we favor public power, we weaken private incentive; but if we favor private power, we lose the strength of the existing price yardstick.

American democracy prides itself on automatic balance-wheels and adjusters which prevent the adoption of extreme policies. The watchdog Joint Committee on Atomic Energy, the General Advisory Committee, and the Military Liaison Committee are such in the governmental structure itself. But an active interplay of influences involving persons and groups outside the Government is also essential for the best operation of these balance-wheels.

Hence, the proliferation of interests centering about the field of atomic power is healthy for American democratic control. Fortunately, the contending forces are so strong and the vested interests so large that no comprehensive settlement of "policy" in favor of one group or another can take place. And this is as it should be in a vital democratic society. 